\title{
Teacher's Perception toward the Use of English for Communication Science Book
}

\author{
Weny Anita Febriantini ${ }^{1}$, Johannes Ananto Prayogo ${ }^{1}$ \\ ${ }^{1}$ Pendidikan Bahasa Inggris-Universitas Negeri Malang
}

\section{INFO ARTIKEL}

\section{Riwayat Artikel:}

Diterima: 20-01-2020

Disetujui: 21-09-2020

\section{Kata kunci:}

\section{perception;}

textbook;

communication;

persepsi;

buku pelajaran;

komunikasi

\author{
Alamat Korespondensi: \\ Weny Anita Febriantini \\ Pendidikan Bahasa Inggris \\ Universitas Negeri Malang \\ Jalan Semarang 5 Malang \\ E-mail: wenyanita11@gmail.com
}

\begin{abstract}
This study aimed at investigating the teachers' perception toward the use of English for Communication Science book and how it facilitates the teaching learning process. Descriptive qualitative research was applied in this study. According to the data obtained from questionnaire and interview, the textbook has fulfilled several criteria of a good book: practicality, language use and content, topics, and tasks. However, it has not fulfilled other criteria: suitability to students, skills mastery, relation to syllabus, and design and organization. In addition, the criteria which facilitate the teaching learning process are language use and content and topics.
\end{abstract}

ABSTRAK

\begin{abstract}
Abstrak: Penelitian ini bertujuan untuk mengetahui persepsi guru terhadap penggunaan buku English for Communication Science dan bagaimana buku tersebut memudahkan dalam proses belajar mengajar. Metode yang digunakan adalah deskriptif kualitatif. Menurut data yang diperoleh dari kuesioner dan interview, buku tersebut telah memenuhi kriteria buku yang baik dalam hal kepraktisan, bahasa dan isi, topic, dan soal latihan, sedangkan belum terpenuhi dalam hal kesesuaian terhadap mahasiswa, penguasaan ketrampilan, kesesuaian dengan silabus, dan desain organisasi. Dengan demikian, kriteria yang dapat memudahkan dalam proses belajar mengajar adalah bahasa dan isi dan topik yang berhubungan dengan jurusan ilmu komunikasi.
\end{abstract}

In this $21^{\text {st }}$ century, the demand of mastering English is undeniable. Despite English is taught as a foreign language in Indonesia, the students are expected to be skillful in English. This purpose of learning English is to equip them to be able to compete in the changing world. Dealing with this purpose, there should be the adequate materials and an effective cooperation between teacher and students. The success in the learning process depends on the role of teachers, students, and materials (Celce-Murcia \& Olshtain, 2000). The importance of materials is related to the existence of textbook in teaching learning process. The materials in the textbook should cover the students' need to learn both the materials and skills since materials and textbooks serves as one of the main instruments for shaping knowledge, attitudes and principles of the students (Noordin \& Samad, 2003). Besides, the textbook also should have the quality concern in terms of interesting layout, practicality, and good design to attract the students' interest in using the textbook. Some functions of textbook such as a source of materials, a source of activities for students to practice communication, and reference source for students on reading especially grammar, vocabulary, pronunciation, and so on (Cunningsworth, 1995). Textbooks also functions as a vehicle for teacher and learner training, a picture of what the change will look like and a psychological support to teachers (Kirkgoz, 2009).

English is not only taught in English department, but it is also taught in non-English department. Teaching English in this case is called English for Specific Purposes (ESP). ESP is an English instruction based on actual an immediate needs of students who have to successfully perform real-life tasks. She added that ESP means learning for the certain purpose within a framework which makes clear and meaningful reasons for learning English (Celani, 2008). Each non-English department students learn ESP based on their major, English for Communication Science for instance. To support the teaching learning process in ESP classroom, the teachers do need a textbook that can provide the suitable materials related to the major which they teach.

Speaking about the teaching learning process in ESP classroom, it must be clearly defined what ESP is. ESP is an English instruction based on actual an immediate needs of students who have to successfully perform real-life tasks. She added that ESP means learning for the certain purpose within a framework which makes clear and meaningful reasons for learning English. Similarly, English for Specific Purposes reflects the students' specific purpose in learning English (Silva, 2002). It is also a response to the students' needs and the acquisition of language relevant to communication outside the classroom, especially in their studies and future careers. It examines the tasks that students require to perform professionally in English. 
Regarding supporting the teaching learning process of English for Specific Purposes (ESP), local textbooks are developed by the university to meet the students' needs, interest, and level of proficiency. The university has an authority to design its own curriculum. In developing ESP textbook, vocabulary is important for several reasons. The importance of vocabulary in ESP textbook means the use of technical words in the particular field (Coxhead, 2013). It includes special purpose, specialized, technical, sub-technical, and semi-technical vocabularies which belong to certain subject area or certain professional discipline. The textbook will make the students aware and get used to the terminology or vocabulary in their area of expertise. After knowing the criteria of the existence of a good textbook in ESP context, evaluating the textbook seems necessary. The teachers and the researchers can take part in this session. The teachers do need to strengthen their theories and conduct experiments reflecting their teaching practice by using the textbook. Their knowledge and experience in the teaching learning process can essentially support the textbook evaluation. The researchers can also help the teachers to do the textbook evaluation. The researcher can provide the necessary aspects in evaluating the textbook. The teacher, the students, and the textbook can be the participant of the research. The result of the research can help the materials developers pay critical attention to the materials arrangement, the vocabulary and grammatical points, language $s$

kills, language teaching methods and the appearance of the book (Ahmadi \& Derahkshan, 2016).

The studies in ESP textbook evaluation are still limited since most of researchers are focusing on the teaching learning process. Here are some previous studies related to ESP textbook evaluation. There is a research about evaluating the contents of two ESP textbooks namely Business Objectives and Business Studies (Fraidan, 2012). He evaluated these textbooks externally and internally since she aimed at content analysis in nature. It is supported by a research that was also about evaluating ESP textbook involving both external and internal aspects (El-Sakran, 2012). His criteria in evaluating the textbook were students' level of proficiency, the content of the textbook, layout, the materials, and the activities for the students.

However, textbook evaluation does not only focus on the content analysis, but it can also talk about the teachers' perception in using the textbook. By gaining the information from the teachers' perspective about the textbook, it can also be called as evaluation because the teachers can relate the syllabus, students' needs, and classroom situation to the textbook. A research was conducted to find the teachers' perception toward the textbook used in the teaching learning process (Diniah, 2013). The textbook used was BSE: Developing English Competencies. There is also a research which focused on teachers' as the subject for his research in evaluating the textbook used in the area of Law department (Wahyudi, 2017). He tried to find out the satisfaction of the teachers and students in using the textbook. The teachers can teach successfully if they enjoy the materials they are employing, it is essential to take teachers' opinions and experiences into consideration (Harbi, 2017).

\section{METHOD}

This study aimed at investigating the teachers' perception toward the use of English for Communication Science book and how it facilitates the teaching learning process. To reach an in-depth description about their perception and the use of the textbook, the writer employed descriptive qualitative approach as the research design. Descriptive qualitative research design aimed at obtaining the data in certain phenomena which is directed to determine the nature of the phenomena as it exists at the same time of the study (Ary et al., 2010). He claimed that it also focuses on providing rich verbal descriptions of settings, situation, and participants.

This study was conducted in Communication Science Department in a private university in Malang. The subjects were seven teachers who taught ESP class for Communication Science students. There were two instruments employed to collect the data namely textbook evaluation questionnaire and interview guide. These instruments were validated by an expert and a practitioner. The textbook evaluation questionnaire was adapted for several previous studies and theories of criteria of textbook evaluation. There were twentyfive statements under eight categories which were developed by adapting from the criteria of textbook evaluation by Ur (2012) and Cunningsworth (1995). After arranging the eight categories, the researcher adapted some statements of the rubric from the existing questionnaires.

The writer used semi structured interview that means the combination of both structured and unstructured in which the interviewer uses a list of questions and also add some questions directly depending on the situation. The writer used this type of interview since there might be additional questions to deliver while doing the interview. There were several steps in collecting the data. Firstly, the writer distributed the textbook evaluation questionnaire to all teachers. Secondly, the data from questionnaire were categorized based on the participants' responses. In this case, the writer selected the two teachers whose responses showed that they were the most frequent and the rarest in using the textbook in the classroom to be the participants for interview. Thirdly, an in-depth interview was conducted to those selected participants who were two teachers. Fourthly, the last step is the writer transcribed the result of the interview.

After finishing collecting the data, the writer analysed the data dealing with the problems under investigation with the steps such as classifying the data from the textbook evaluation questionnaire and interview based on the statement of the problems, categorizing the total of the participants' responses from the textbook evaluation questionnaire, analyzing the result of the interview, and drawing the result from both questionnaire and interview in form of narrative description. 


\section{FINDINGS}

\section{Teachers' Perception toward the Use of English for Communication Science Book}

The data of teachers' perception toward the use of English for Communication Science book is from the questionnaire. The result of questionnaire is performed in the data of each category of the questionnaire. The category is performed as follows:

\section{Perception on suitability of the textbook to the students}

The table below shows the perception of teachers on the suitability of the textbook to the students. This category is broken down into two statements as follows:

Table 1. Teachers' Responses

\begin{tabular}{clllll}
\hline No. & \multicolumn{1}{c}{ Statements } & Strongly Disagree & Disagree & Agree & Strongly Agree \\
\hline 1 & The textbook is compatible to the students' level of proficiency. & - & 5 & 2 & - \\
2 & The textbook is compatible to the students' needs. & - & 4 & 3 & -
\end{tabular}

The table shows that most of the teachers think that the textbook is not compatible to the students' level of proficiency since there are five teachers who disagree over only two teachers who agree with the statement. In line with the first statement, the number of teachers who disagree with the second statement is also higher than the teachers who agree with the statement. Most of them believe that the textbook is not compatible to the students' needs since there are four teachers who disagree over three teachers who agree with the statement.

\section{Perception on practicality of the textbook to the students}

The table below shows the perception of teachers on the practicality of the textbook to the students. This category is broken down into three statements as follows:

Table 2. Teachers' Responses

\begin{tabular}{llllll}
\hline 1 & Statements & Strongly Disagree & Disagree & Agree & Strongly Agree \\
\hline 1 & The textbook is affordable. & - & 2 & 1 & 4 \\
2 & The textbook is easy to carry. & 1 & - & 2 & 4 \\
3 & The textbook is durable. & - & 1 & 3 & 3 \\
\hline
\end{tabular}

The table shows that the teachers mostly agree and even strongly agree with the three statements about the practicality of the textbook. The five teachers believe that the textbook is affordable since the payment of the textbook is included in the tuition, so the students do not need to pay more money to buy the textbook. If it comes to the size of the textbook that can affect the way the students bring the textbook easily or not, only one teacher shows his disagreement while most of the teachers agree that the textbook is easy to carry since the textbook is actually A5 size. Furthermore, the practicality of the textbook is also based on its durability. There is only one teacher who showed his disagreement compared to the six teachers do agree that the textbook is durable. Thus, the teachers mostly agree with the three statements about the practicality of the textbook in terms of the price, the easiness to carry, and durability.

\section{Perception on Language Use and Content in the Textbook}

The table below shows the perception of teachers on language use and content in the textbook. This category is broken down into five statements as follows:

Table 3. Teachers' Responses

\begin{tabular}{|c|c|c|c|c|c|}
\hline No. & Statements & $\begin{array}{l}\text { Strongly } \\
\text { Disagree }\end{array}$ & Disagree & Agree & Strongly Agree \\
\hline 1 & The language use is suitable for the students' level of proficiency. & - & 4 & 3 & - \\
\hline 2 & The textbook has an appropriate glossary. & - & 3 & 4 & - \\
\hline 3 & The reading materials are sufficient, varied, and interesting. & - & 3 & 4 & - \\
\hline 4 & The content and language in the textbook are comprehensible. & - & 4 & 3 & - \\
\hline 5 & $\begin{array}{l}\text { Reading texts and the associated activities are suitable for the students' level } \\
\text { of proficiency. }\end{array}$ & - & 3 & 4 & - \\
\hline
\end{tabular}


The table shows that the teachers' perception is balanced in between disagree and agree. If it comes to the language use in the textbook, there are four teachers who disagree while three agree. It means that the teachers who agree with the statement believe that the language use in the textbook is in the same level as the students' level of proficiency while the teachers who disagree with the statement believe that the language use is whether too high or easy that can affect the suitability to the students' level of proficiency. Then, the next statement is about the appropriateness of the glossary. The four teachers show their agreement while the three teachers show the opposite.

Next statement is about the reading materials. The four teachers do agree that the textbook provides sufficient, varied and interesting reading materials. On the other hand, the three teaches show their opposite perception which means thy think that the available reading materials in the textbook are not sufficient, varied and interesting yet. On the other hand, the teachers show their opposite perception from the former statement. The statement is about the comprehensible content and the language in the textbook. The four teachers show their disagreement while three teachers show their agreement. The last statement about language and content is the association between the reading text and the activities to the students' level of proficiency. Four teachers do agree that the activities are associated with the reading text based on the students' level of proficiency while three teachers disagree with that statement.

\section{Perception on Skills Mastery in the Textbook}

The table below shows the perception of teachers on skills mastery in the textbook. This category is broken down into two statements as follows:

Table 4. Teachers' Responses

\begin{tabular}{clllll}
\hline No. & Statements & Strongly Disagree & Disagree & Agree & Strongly Agree \\
\hline 1 & The textbook covers adequately all four skills. & 6 & 1 & - & - \\
2 & The activities in the textbook promote the students' English skills. & - & 3 & 4 & - \\
\hline
\end{tabular}

The table shows that all teachers believe that the textbook does not cover all four skills since the fact is the textbook provides reading, speaking, and writing skills without listening. Thus, all teachers disagree with the statement. However, the statement of the activities in the textbook promotes the students' English skills allow the teachers has two kinds of perception. Four teachers agree with the statement while three teachers show their disagreement. It is assumed that the textbook can successfully promote the students' English skills in several classes depending on the students' English mastery.

\section{Perception on Topics in the Textbook}

The table below shows the perception of teachers on topics in the textbook. This category is broken down into four statements as follows:

Table 5. Teachers' Responses

\begin{tabular}{|c|c|c|c|c|c|}
\hline No. & Statements & $\begin{array}{l}\text { Strongly } \\
\text { Disagree }\end{array}$ & Disagree & Agree & Strongly Agree \\
\hline 1 & The topics are up-to-date. & 3 & 3 & 1 & - \\
\hline 2 & The textbook covers a variety of topics. & - & 5 & 1 & 1 \\
\hline 3 & The topics are about communication science field. & - & - & 4 & 3 \\
\hline 4 & The vocabularies are specialized in the area of communication science. & - & 2 & 4 & 1 \\
\hline
\end{tabular}

The four statements in the table above are about the topics in the textbook. First, almost most of the teachers disagree that the topics are up-to-date while only one teacher who agrees with the statement. The teachers mostly also show their disagreement that the textbook covers variety of topics. There are five teachers believe that the textbook does not provide various topics over two teachers who agree with the statement. However, all the teachers agree that the topics in the textbook are about communication science field because the textbook is specifically for communication science department. In line with former statement, the teachers mostly agree that the vocabularies in the textbook are specialized in communication science field. When the topics are already about communication science field, the vocabularies are automatically in the same field.

\section{Perception on the Textbook Relation to Syllabus}

The table below shows the perception of both teachers and students on the textbook relation to syllabus. This category is reflected in one statement as follows: 
Table 6. Teachers' Responses

\begin{tabular}{clllll}
\hline No. & Statements & Strongly Disagree & Disagree & Agree & Strongly Agree \\
\hline 1 & The textbook is designed based on the syllabus. & 1 & 2 & 3 & 1 \\
\hline
\end{tabular}

From table above, the teachers have different perception toward the relation between the textbook and syllabus. There are four teachers who agree over the three teachers who disagree with the statement. Their perception might be affected by the change of syllabus. The current syllabus actually has been modified from the former syllabus when the textbook was created. So, that is why some teachers think that the textbook is based on the syllabus and some of them do not think the same way.

\section{Perception on Design and Organization}

The table below shows the perception of teachers on design and organization. This category is broken down into two statements as follows:

Table 7. Teachers' Responses

\begin{tabular}{clccc}
\hline No. & \multicolumn{1}{c}{ Statements } & $\begin{array}{c}\text { Strongly } \\
\text { Disagree }\end{array}$ & Disagree & Agree \\
\hline 1 & The textbook is attractive in terms of picture, color, and design. & 2 & 5 & - \\
2 & $\begin{array}{l}\text { The structure of the textbook is in order in term of the level of } \\
\text { difficulty. }\end{array}$ & - & 5 & - \\
\hline
\end{tabular}

The table shows that the teachers disagree that the textbook has an attractive design, picture, and color. Their perception is supported by the fact that the textbook has a low quality of paper. It makes the black and white color of the textbook' more unclear. Then, dealing with the structure of textbook in terms of the level of difficulty, the teachers mostly disagree with the statement. The factors can be from the structure of the content and the task. They might think that the content and the task are randomly designed in terms of the level of difficulty.

\section{Perception on Exercises/ Tasks in the Textbook}

The table below shows the perception of teachers on exercises/ tasks in the textbook. This category is broken down into six statements as follows.

Table 8. Teachers' Responses

\begin{tabular}{|c|c|c|c|c|c|}
\hline No. & Statements & $\begin{array}{l}\text { Strongly } \\
\text { Disagree }\end{array}$ & Disagree & Agree & Strongly Agree \\
\hline 1 & The tasks improve the students' English language skills. & - & 3 & 4 & - \\
\hline 2 & Task difficulties move from simple to complex. & - & 5 & 2 & - \\
\hline 3 & The tasks contain fun activities. & - & 7 & - & - \\
\hline 4 & Every task has a clear instruction. & - & 1 & 5 & 1 \\
\hline 5 & $\begin{array}{l}\text { The textbook provides a variety of challenging activities to practice } \\
\text { language items and skills. }\end{array}$ & - & 1 & 6 & - \\
\hline 6 & $\begin{array}{l}\text { The textbook provides a variety of meaningful exercises to practice } \\
\text { language items and skills. }\end{array}$ & - & 2 & 5 & - \\
\hline
\end{tabular}

The table shows that the teachers stand on two sides. Four teachers agree that the tasks in the textbook improve the students' English language skill while three teachers disagree with that statement. Concerning the task arrangement, almost most of them disagree that the tasks move from simple to complex. There are only two teachers who agree with that statement. Furthermore, all seven teachers disagree that the tasks contain fun activities. It is because the textbook has repetitive activities from one unit to another. So it can make the students bored in doing the tasks. Then, almost all the teachers agree that the task has a clear instruction since every task is supported by an example. Moreover, most of the teachers also agree that the textbook provide various challenging activities to practice the students' skills. The last statement is about various meaningful activities. Five teachers agree with the statement but two teachers do not agree.

\section{How English for Communication Science Book Facilitates the Teaching Learning Process}

The data of how English for Communication Science Book facilitates the teaching process is gained from the interview teachers. The two teachers are those who are the most frequent and the rarest in using the textbook in the classroom. The interview was conducted in the seventh meeting or a half of the semester since it was a week before midterm test. Thus, there are several aspects which the teachers consider whether they use the textbook or not in the classroom. The teacher who has not used the 
textbook yet in his class mentions several reasons why he did that way in his teaching learning process. Those reasons are related to his perception on the use of textbook to facilitate him in the teaching learning process. Here is his perception in form of the table based on the eight categories.

Table 9. Teacher's Perception on How the Textbook Facilitates Him in the Teaching Learning Process

\begin{tabular}{|c|c|}
\hline Category of Textbook & Teacher's Perception \\
\hline $\begin{array}{l}\text { The suitability of the textbook } \\
\text { to the students }\end{array}$ & $\begin{array}{l}\text { He thinks that the text in the textbook is hard for his students for the several beginning meetings since his } \\
\text { students are mostly beginner level in English. }\end{array}$ \\
\hline $\begin{array}{l}\text { Practicality of the textbook to } \\
\text { the students }\end{array}$ & $\begin{array}{l}\text { He thinks that the textbook has strength in term of practicality since the textbook is small enough to carry } \\
\text { wherever the students go. }\end{array}$ \\
\hline $\begin{array}{l}\text { Language use and content in } \\
\text { the textbook }\end{array}$ & $\begin{array}{l}\text { Although his students feel that the text in the textbook is hard, he believes that the textbook can still } \\
\text { facilitate the teaching learning process in the class with the advanced students. }\end{array}$ \\
\hline Skills mastery in the textbook & $\begin{array}{l}\text { He extremely highlights that the textbook does not facilitate him when he teaches listening since the } \\
\text { textbook only provides three skills such as reading, writing, and speaking. }\end{array}$ \\
\hline Topics in the textbook & $\begin{array}{l}\text { He thinks that the textbook provides various topics about communication science, yet those topics are still } \\
\text { hard for his students. }\end{array}$ \\
\hline Textbook relation to syllabus & $\begin{array}{l}\text { He assumes that the textbook does not facilitate all topics based on the current syllabus since it was } \\
\text { designed in } 2014 \text { while the latest syllabus was designed in } 2017 .\end{array}$ \\
\hline Design and organization & $\begin{array}{l}\text { He argues that it is okay if the textbook is black and white colour as long as the quality of the paper is } \\
\text { good, the picture and all the content inside the textbook will be good as well. }\end{array}$ \\
\hline $\begin{array}{l}\text { Exercises/ tasks in the } \\
\text { textbook }\end{array}$ & $\begin{array}{l}\text { The activities of the task in the textbook are mostly repetitive. This way, the students will get bored and } \\
\text { not interested in doing the same activities all over again. }\end{array}$ \\
\hline
\end{tabular}

Another perception comes from the teacher who always uses the textbook in every meeting since the second week. This teacher also has her own considerations that affect her decision to use the textbook frequently. Here is her perception on the use of textbook to facilitate her in the teaching learning process based on the eight categories.

Table 10. Teacher's Perception on How the Textbook Facilitates her in the Teaching Learning Process

\begin{tabular}{|c|c|}
\hline Category of Textbook & Teacher's Perception \\
\hline $\begin{array}{l}\text { The suitability of the textbook } \\
\text { to the students }\end{array}$ & $\begin{array}{l}\text { She says that the textbook is not suitable to the students' level of proficiency because most of the students } \\
\text { in her classroom are still hard when they use textbook. But, she thinks the textbook still helps her to give } \\
\text { the materials to the students by thinking about the best way to deliver to them. }\end{array}$ \\
\hline $\begin{array}{l}\text { Practicality of the textbook to } \\
\text { the students }\end{array}$ & She believes that the textbook is practical enough since the size of the textbook is medium-size. \\
\hline $\begin{array}{l}\text { Language use and content in } \\
\text { the textbook }\end{array}$ & $\begin{array}{l}\text { She thinks that the texts in the textbook do facilitate the students to be familiar with the vocabularies in } \\
\text { the area of communication science. So, she can see the improvement of her students' vocabularies. }\end{array}$ \\
\hline Skills mastery in the textbook & $\begin{array}{l}\text { She absolutely argues that the textbook does not cover all the skills since it does not provide the materials } \\
\text { of listening skill. }\end{array}$ \\
\hline Topics in the textbook & $\begin{array}{l}\text { She knows that the topics in the textbook are mostly out-of-date, yet she still tries to maximize the use of } \\
\text { the textbook by choosing the up-to-date topics in the textbook and finding other latest sources related to } \\
\text { the topics in the textbook as the supplementary materials. }\end{array}$ \\
\hline Textbook relation to syllabus & $\begin{array}{l}\text { She realizes that the textbook was designed in } 2014 \text { that makes it no longer totally based on the latest } \\
\text { syllabus which was designed in } 2017 .\end{array}$ \\
\hline Design and organization & $\begin{array}{l}\text { She thinks that some pictures in the textbook are childish that are not relatable to the college students' real } \\
\text { life. The organization is also randomly arranged in terms of level difficulty. This way, she argues that the } \\
\text { textbook does not facilitate the teaching learning process in terms of design and organization. }\end{array}$ \\
\hline $\begin{array}{l}\text { Exercises/ tasks in the } \\
\text { textbook }\end{array}$ & $\begin{array}{l}\text { The format of the task is monotonous. Thus, in term of the task, she can say that the task do not facilitate } \\
\text { to improve the students' skills well. }\end{array}$ \\
\hline
\end{tabular}




\section{DISCUSSION}

\section{Teachers' Perception toward the Use of English for Communication Science book}

The suitable textbook to the students are undeniably important. ESP textbook will be beneficial for the students to master English if the textbook is compatible with the students' need (Ghalandari \& Talabinejad, 2012). The textbook should concern the relevance of the textbook to the learners' needs (Yakhontova, 2001). Moreover, the textbook also must be suitable to the students' level of proficiency. The vocabularies and grammar in the textbook must be appropriate to the students' level of proficiency. It concerns to make the textbook understandable and helpful to the students (Richard, 2001). In term of suitability of the textbook to the students' level of proficiency and students' needs, the findings show that the number of teachers who disagree with the statement is higher than those who agree. It shows that the textbook might be either lower or higher than the students' level of proficiency and also no longer suitable with the current students' needs due to the textbook time created. It is assumed that the teachers have different perception based on their experience in using the textbook. Thus, the textbook must be exactly based on the students' needs and level of proficiency based on the teachers' perception.

The practicality of the textbook needs to be considered as well as the suitability does. The textbook must be affordable and a convenient package (Ur, 2012). Because of the heterogeneous economic backgrounds, the cost of the textbook becomes a concern. If the cost of the textbook is affordable for all of the levels, the students can own the textbook and use it for studying both at home and at class. Furthermore, the textbook must be bound, stick together, and in order. Its size must be easy to carry around. Those aspects can make the students not lazy to bring the textbook wherever they go. Based on the findings, teachers mostly agree with the statements of the practicality criteria. It reveals that the textbook already fulfill the criteria of textbook practicality. It is supported by the fact that the students do not need to pay more money to buy the textbook since it is include their tuition. Then, due to its size, the textbook is compact and small enough to carry. In a result, teachers see that the textbook meet the practicality of a good textbook. It just needs to keep its quality in terms of its price, durability, and easiness to carry.

Language use and content do play crucial aspects in the criteria of a good textbook. The use of language and the materials are the two of his criteria (Crawdford, 2002). He said that the language development must reflect the use of language and various materials. The textbook must provide adequate glossaries to support their language and materials improvement (Bhatia et al., 2011). The materials are designed related to the curriculum, situations, task requirements, and needs of the mentioned major of study (Karimnia \& Jafari, 2017). The content of the textbooks must be also realistic, interesting, challenging, motivating, with sufficient variety of topics (Riasati \& Zare, 2010).

Dealing with the language use and content from the teachers' perception, the findings show that their agreement and disagreement are balanced. Half of them agree and disagree with the statements. It means that the textbook has already fulfilled the criteria of a good textbook in terms of language use and content while the opposite believes it has not fulfilled yet. It is assumed that half of the teachers believe that the language use in the textbook is in the same level as the students' level of proficiency while the others believe that the language use is whether too high or easy. Then, in term of glossary, despite each reading text already has glossary related to the text, the teachers have different perception whether the glossary is already appropriate or not. Next, half of them give their perception that the reading materials are sufficient, varied, and interesting while the others have opposite perception. Furthermore, most of the teachers might think that the content and language in the textbook are hard to understand by the students. So, it can lead their perception to their disagreement. The last, the teachers may have different experience when they discuss the reading text and associated activities in the classroom, so it leads their agreement and disagreement whether those are suitable to the students' level of proficiency or not.

In term of language skill mastery, the four skills of English such as listening, reading, speaking, and writing must be accessible to learn for the students. According to Richard (2001), textbook should be acceptable and balanced between the relevant language skills and how to integrate them. It also contains communicative activities to promote the students' participation. Based on the findings, the textbook does not provide all skills because there is no listening material inside the textbook. It is proven by the teachers' perception which shows agreement that the textbook does not cover all skills to be learnt by the students. However, the students' can improve their English skills except listening skill by using the textbook. It is reflected by the teachers' perception which shows their agreement and disagreement. It is assumed that the textbook can successfully promote the students' English skills in several classes among all depending on the students' English mastery. In sum, it reveals that the textbook has only one weakness in term of providing all skills since only listening skill must be added in the textbook among the four English skills.

Topics may take an important part of an ESP textbook since an ESP textbook must offer specific materials of a certain discipline area. This way, Richard (2001) said that specific materials have a positive effect to students' motivation because they can relate more closely to their needs. The materials in textbook must reflect what the students' need in doing their profession later on to help them master English in their disciplines (Robinson, 1991). The findings reveal that the textbook does not cover up-to-date and variety topics based on the teachers' perception. The teachers' disagreement might be caused by the topics in the textbook are not current topics since the textbook was created in 2014. The topics can be up-to-date at the time when the textbook was created. Yet, they still have a positive perception toward the topics and the vocabularies are specialized in the area of communication science. They found that all topics in the textbook are about communication science. When the topics are already about communication science field, the vocabularies are automatically in the same field. Thus, the textbook really needs to improve its variety of topics. The textbook needs to provide up-to-date topics as well. Those aspects are intended to make the students aware the latest issues in their field of study. 
Syllabus plays crucial role in the teacher learning process since it is consist of materials implemented in the classroom. Consequently, the textbook used in the classroom must be based on the syllabus to completely help the teachers in delivering the materials. Textbook should have a good structure based on the syllabus (O’Neil, 1982). It makes both teachers and students can easily preview the previous materials and review the next materials. Ur (2012) added that textbook serves as a syllabus which means the content in the textbook should systematically cover the syllabus. It functions to maximize the use the textbook in the teaching learning process. The findings show that teachers have balanced perception between agreement and disagreement. It might be caused by the current syllabus actually has been modified from the former syllabus when the textbook was created. So, that is why some teachers might think that the textbook is based on the syllabus and some of them do not think the same way. In a result, the textbook is certainly based on the former syllabus when the textbook was created, not the latest one. That makes some topics and materials in the latest syllabus do not exist in the textbook. This way, if the teachers want to give the materials that are not available in the textbook, they must figure it out by finding the materials by themselves.

In terms of design, Crawdford (2002) defined that one of the eight criteria of a good textbook includes visual component. As (Sarem et al., 2013) stated that the textbook should have variety of beautiful, colourful, and real pictures which serve two main functions such as making the book and its content very appealing and motivating the students and providing a meaningful context for each activity and help students to understand the materials and make sense of the tasks better. It means that the textbook' appearance must be able to attract the students' interest. If the students are interested in using the textbook, they automatically can enjoy the teaching learning process. Furthermore, organization is an important part as well. If the textbook has a good organization, the teachers and students will get easy to use the textbook in the classroom. It is argued by (Ur, 2012) who underlined that a textbook must provide a clear framework. It means that the teachers and students know what they have learned and what comes next. It is only a matter of structure and progress.

The findings show that all the teachers disagree that the textbook is attractive and has a good order in terms of level of difficulty. Their perception is based on the fact that the textbook has a low quality of paper which makes the black and white color of the textbook more unclear. Moreover, the pictures in the textbook sometimes use cartoon that seems not represent the textbook for university students. Then, the factor that affects their perception on the organization might be from the structure of the content and the task. They might think that the content and the task are randomly designed in terms of the level of difficulty. In terms of the existing exercises/ tasks in the textbook, some criteria should be fulfilled in order to make optimal use of the textbook to practice their language skills. Ur (2012) also mentioned the textbook also must be appropriate for the level of proficiency of the students. If the level of difficulty of the tasks is suitable with the students' level proficiency, it can be concluded that the textbook can use effectively in the teaching learning process.

The findings reveal that the teachers have a negative perception on the level of difficulty of the task arrangement and the attractiveness of the activities. It is assumed that the tasks in the textbook move randomly (not from simple to complex) and also the activities are not fun to do. On other hand, most of the teachers agree that the textbook has already a clear instruction. Its tasks are also various, challenging, and meaningful which can enhance the students' English language skills. Those might happen in some classes since there are some teachers who show disagreement. They might think that the textbook does not help them enough to improve their students' English skills in the classroom. Their perception depends on the result of their classroom activity. However, the teachers believe that the textbook has clear instruction that can ease them to do the tasks. It also has challenging and meaningful activities to improve the students' English skills. This perception can be from the experience which show that the activities in the textbook work well in most of the classes.

\section{How English for Communication Science Book Facilitates the Teaching Learning Process}

To make the textbook can facilitate the teachers and the students in the teaching learning process, the first aspect to consider is the textbook must be based on the syllabus. If the textbook has been already based on the syllabus, the teachers do not need to look for other materials to teach since the materials are available in the textbook. It is in line with Ur (2012) who argued that textbook is guidance for teachers since it is designed based on the syllabus. This way, it will provide the materials that can be used in the teaching learning process. In fact, the findings show that both teachers textbook agree that the materials in the textbook are no longer based on the current syllabus since the textbook was designed over five years ago. It means that the textbook was designed based the syllabus at that time. Consequently, there are some materials that they need to teach in the classroom are not available in the textbook. This situation forces them to find their own materials from other sources. As a result, the teachers think that the textbook is not helpful enough to provide the materials related to the syllabus.

The second aspect is about the materials. The materials are the main aspect in the teaching learning process since the materials present a list of discourse markers fulfilling a particular textual function (Kiely, 2009). The teachers need to deliver the materials that must be suitable to the students' need and level of proficiency in order to reach the maximum learning goals. Speaking about the materials and students need, students who learn ESP must meet their specific needs related to their area of discipline (Gatehouse, 2001). In addition, the good criteria of textbook must be suitable to the students' needs, interest, and level of proficiency (Kitao \& Kitao, 1997). This concern will make the textbook understandable and useful for the students to learn.

Dealing with the students' need, the findings show that the textbook has already provided the materials about communication science department. It means that the textbook has facilitated the teachers in improving their students' vocabulary enrichment. Designing ESP textbooks must be in line with the students' needs, interests and expectations in order to help them 
develop the beneficial language skills for their academic studies and familiarize them with the genre of their study (Hashemi et al., 2011). The students can learn the materials about their field of study in the textbook. The subject and content of the textbook must be relevant to the students' needs at language institutes in that they may raise learners' awareness and increase their positive attitude toward the target language (Alemi \& Sadehvandi, 2012). However, dealing with the students' level of proficiency, both teachers say that the textbook is hard for their students. The teachers need to figure it out by their own ways. Creative teachers/lecturers will see this chance as the greatest flexibility and encourages the development of material strategies to focus on the learner needs. They can find another source which is lower level than in the textbook yet it has the same topic (Suhirman, 2018). Then, they can only discuss that another source or they can discuss it first before going to the topic in the textbook. As a result, the textbook can facilitate the teaching learning process in term of providing the materials related to the students need (learning about communication science), but it does not really help the students in term of level of proficiency.

The last aspect is the tasks in the textbook. The tasks take an important role as well as the materials. A good textbook does not only encompasses a variety of tasks to make students ready to carry communicative tasks in real life but its exercises also should be representative of the lessons in the book (Azizifar \& Baghelani, 2014). The role of the tasks is to help the students practice their language skills after gaining the materials adequately. As Ur (2012) said that the textbook provides tasks that must be appropriate for the students' level of proficiency. If the level of difficulty of the tasks is suitable with the students' level proficiency, it can be concluded that the textbook can be used effectively in the teaching learning process. In fact, based on the findings, the textbook provides the same repetitive format of tasks. This might help them to improve their language skills in the first time they do the tasks, but it will be useless if they do the same monotonous format in the next activities. It is because the students repeat doing the same format of tasks which does not let them challenge themselves anymore in doing the tasks. As a result, the textbook will help the students improve their language skills by doing the tasks in the very first time, yet they will get boring tasks if they do the same format later on. This way, the teachers must be creative to offer other challenging tasks if they find the same format of the tasks that they have did before.

\section{CONCLUSIONS}

Based on the results obtained from the findings and discussion, it can be concluded that in general, the teachers have different perception toward the textbook. To the teacher, the textbook has already met some criteria of a good textbook. Those fulfilled aspects have helped them and their students in the teaching learning process. Those fulfilled aspects are the practicality of the textbook, language use and content, and the topics which are all about communication science. On the other hand, there are some unfulfilled aspects such as the available materials related to syllabus, the numerous activities to improve the students' English skills, and the arrangement of the tasks which must move from simple to complex. The teachers do consider every aspect which facilitates them in the teaching learning process since they know how to teach their students in the classroom well.

Based on the findings of the study, the suggestions are given to the three parties related to ESP textbook such as the next book writers, the ESP teachers, and the future researchers. First suggestion is for the book writers who will revise the textbook. The first thing to do in revising the textbook is look at the current syllabus. If the syllabus has been already suitable with the students' need, the book writers only pick the topics and develop them into good materials in the textbook. If the textbook is based on the latest syllabus, the teachers will use the textbook effectively. Furthermore, the book writers can pay more attention to the pictures and the format activities. The pictures which exist in each task can be more relatable to college students which will make them interested in doing the task. The format of the tasks can be more various, interesting, and comprehensible.

Second suggestion is for ESP teachers who teach Communication Science department. By knowing the weakness of the textbook, the teachers are expected to decide what will help them in delivering the materials effectively. They are intended to provide the supplementary materials if the materials are not available in the textbook or the materials in the textbook are too hard for their students. The last suggestion is for future researchers. Since this research was conducted in the middle of the first semester, the findings can be still in the surface. Thus, to gain deeper results, it would be better to conduct the research in the end of the second semester due to the longer use of the textbook. Then, it is also suggested to conduct a research focusing on content analysis for the same English textbook. It will give more accurate and valuable results since the concerns are only the content based on the criteria of a good textbook.

\section{REFERENCES}

Ahmadi, A., \& Derahkshan, A. (2016). EFL Teachers' Perceptions towards Textbook Evaluation. Theory and Practice in Language Studies, 6(6), 260-267.

Alemi, M., \& Sadehvandi, N. (2012). Textbook Evaluation: EFL Teachers' Perspectives on “Pacesetter Series.” English Language Teaching, 5(7), 64-74.

Ary, D., Jacobs, C. L., \& Razavieh, A. (2010). Introduction to Research in Education (Eight). Nelson Education Ltd.

Azizifar, A., \& Baghelani, E. (2014). Textbook Evaluation from EFL Teachers' Perspectives: The Case of "Top-Notch" Series. International SAMANM Journal of Business and Social Sciences, 2(1), 22-41.

Bhatia, V., Anthony, L., \& Noguchi, J. (2011). ESP in the $21^{\text {st }}$ Century: ESP Theory and Application Today. Proceedings of the JACET 50th Commemorative International Convention. 
Celani, M. A. A. (2008). When Myth and Reality Meet: Reflections on ESP in Brazil. English for Specific Purposes, 27, 412423.

Celce-Murcia, M., \& Olshtain, E. (2000). Discourse and Context in Language Teaching; a Guide for Language Teachers. Cambridge University Press.

Coxhead, A. (2013). Vocabulary and ESP. In The Handbook of English for Specific Purposes (First). John Wiley \& Sons, Inc.

Crawdford, J. (2002). The Role of Materials in the Language Classroom: Finding the Balance, in Methodology in Language Teaching: An Anthology of Current Practice. Cambridge University Press.

Cunningsworth, A. (1995). Choosing Your Course book. Oxford: Mcmillan Education.

Diniah, S. N. (2013). Teachers' Perceptions Towards the Use of English Textbook in EFL Classrooms Descriptive Study of EFL Teachers at One Islamic Senior High School in Cirebon). Journal of English Education, 1(1), 185-195.

El-Sakran, A. T. (2012). Evaluation of an English for Specific Purposes (ESP) Book for Students of Islamic and Arabic Studies. English for Specific Purposes World, 34(12).

Fraidan, A. A. (2012). Evaluation of Two ESP Textbooks. English Language Teaching, 5(6), 43-47.

Gatehouse, K. (2001). Key issues in English for Specific Purposes (ESP) Curriculum Development. The Internet TESL J, 7, 10.

Ghalandari, S., \& Talabinejad, M. R. (2012). Medical ESP Textbook Evaluation in Shiraz Medical College. Education Research Journal, 2(1), 20-29.

Harbi, A. A. M. A. (2017). Evaluation Study for Secondary Stage EFL Textbook: EFL Teachers' Perspectives. English Language Teaching, 10(3), 26-39.

Hashemi, M. R., Lamir, A. R., \& Namjoo, F. R. (2011). English for B. Sc. Students of Physical Education in Iran: A Study of Perception of English Needs and Effectiveness of ESP Textbooks. English Language and Literature Studies, 1(2), 14-24.

Karimnia, A., \& Jafari, F. M. (2017). Critical ESP Textbook Evaluation: The Case of Visual Arts Textbook. Research Gate, 11 , 219-2366.

Kiely, R. (2009). Small Answers to the Big Question: Learning from Language Programme Evaluation. Language Teaching Research, 13(1), 99-116.

Kirkgoz, Y. (2009). Evaluating the English Textbooks for Young Learners of English at Turkish Primary Education. Social Behavioral Sciences, 1, 79-83.

Kitao, K., \& Kitao, K. S. (1997). Selecting and Developing Teaching/Learning Materials. TESL Journal, 4(4).

Noordin, N., \& Samad, A. A. (2003). Examining the Importance of EST and ESL Textbooks and Materials: Objectives, Content and Form. ESP World, 1(4), A-9.

Riasati, M. J., \& Zare, P. (2010). Textbook Evalyation: EFL Teachers' Perspectives on "New Interchange." Studie in Literature and Language, 1(8), 54-60.

Sarem, S. N., Hamidi, H., \& Mahmoudie, R. (2013). A Critical Look at Textbook Evaluation: A Case Study of Evaluating an ESP Course-Book: English for International Tourism. International Research Journal of Applied and Basic Sciences, 4(2), 372-380.

Silva, F. (2002). ESP Teaching for Learner in the Health Science Field (pp. 35-40).

Suhirman, L. (2018). ESP Textbook Evaluation: English for Islamic Learning for College Students. IJOLTI, 3(1), $13-22$.

Ur, P. (2012). A Course in Language Teaching. Cambridge University Press.

Wahyudi, A. (2017). ESP Textbook Evaluation: English for Law.

Yakhontova, T. (2001). Textbooks, Contexts, and Learners. English for Specific Purposes, 20, 397-415. 